\title{
OPTIMIZATION OF MEDIUM FOR ENHANCING BACTERIOCIN PRODUCTION BY MARINE Lactobacillus rhamnosus L43 USING STATISTICAL DESIGN.
}

\author{
B. P. Wadekar and Dharmadhikari S. M. \\ ZSCT's Thakur College of Science, Kandivali (E), Mumbai. \\ Department of Microbiology, Government College of Science and Art, Aurangabad \\ Email id: bharti.wadekar@gmail.com
}

\begin{abstract}
:
Media composition and growth conditions influence the culture growth of Lactobacillus rhamnosus L43 and the antibacterial performance. The Plackett-Burman design, steepest ascent path design and central composite design provides an efficient way of a large number of variables and identifying the most important ones. Different statistical designs prepared and carried step by step, observed and predicted result using software Minitab 14 and design Expert Version 9. According to PB design and based on low $\mathrm{p}$ value, significant components were found to be lactose, peptone, yeast extract, $\mathrm{MgSO}_{4}, \mathrm{KH}_{2} \mathrm{PO}_{4}$, $\mathrm{K}_{2} \mathrm{HPO}_{4}, \mathrm{NaCl}$ had a significant influence (at 95\% significant level) on Bacteriocin production. The optimization medium included lactose of concentration of $20 \mathrm{gm} / \mathrm{L}$, peptone of concentration of $10 \mathrm{gm} / \mathrm{L}$ and $\mathrm{MgSO}_{4}$ of concentration of $0.10 \mathrm{gm} / \mathrm{L}$. Predicted value of the diameter of zone of inhibition against Escherichia coli was $19.66 \mathrm{~mm}$ by RSM method and data validation report. The mMRS medium gave the highest yield of bacteriocin as well as reduced the cost of medium.
\end{abstract}

Keywords: Lactobacillus rhamnosus L43, Escherichia coli (1687), MINITAB 14, Design Expert 9, PBD, RSM.

\section{INTRODUCTION:}

The biological antimicrobial substances have increased research attention to their potential in food bio preservation as purified metabolites, through the use of their producer strains in the starter culture (Chen and Hoover, 2003). Therefore, there has been a continuous need to define the most appropriate condition for bacteriocin production in fermentation media and food systems. The optimization is a process which includes the adjustment of internal and external parameters for the maximum production. Growth media compositions and environmental factors such as $\mathrm{pH}$, temperature have some influence for production of antibacterial compounds. MRS broth remains the most widely used culture medium for growth of LAB (Todorov and Dicks, 2006). Certain components, such as carbohydrates, salts, nitrogen sources, surfactants or oxygen tension reducing agents added to the MRS broth can interfere with bacteriocin production (Keren et al., 2004; Mataragas et al., 2004; Trinetta et al., 2008; Todorov, 2008; Abo-Amer et al., 2011, Castro et al., 2011). These factors need to evaluate and achieve optimized bacteriocin production for industrial applications. Bacteriocin production in Lactobacillus sp. is dependent on multiple factors and is usually a strain specific phenomenon. Nowadays, statistical models are available for the optimization process such as Factorial, Fractional factorial, Plackett- Burman, Taguchi, 
Response Surface Methodology (RSM), Polynomial and rational modelling, Box-Menken and Central composite design. The use of Plackett Burman Design (PBD) and response surface methodology (RSM) has a history of successful application in many fields, especially biotechnology, and suited for the study of the effects of distinct factors on bacteriocin production (Cladera-Olivera et al., 2004; Kumar et al., 2012, Suganthi and Mohanshrinivasan, 2015). Response surface methodology is one of the effective statistical and mathematical technique used for developing, improving and optimizing the complex process in the experiments, building models, evaluating the effects of factors, and searching optimum conditions of factors for desirable responses (Leal-Sanchez et al., 2002).

In this study, we have reported optimization of nutritional parameters of which have direct influence on the growth of bacterial strain Lactobacillus rhamnosus L43 and production of bacteriocin by statistical method.

\section{MATERIAL \& METHODS:}

\section{1.a Bacterial strains:}

The bacteriocin-producing strain used in this study was Lactobacillus rhamnosus. L43 which was isolated from Gopalpur beach, Orrissa (water) . The strain used as the indicator microorganism was Escherichia coli MTCC 1687. Stock cultures were maintained at $-4^{\circ} \mathrm{C}$ in MRS medium containing 20\% glycerol..

\section{1.b Bacteriocin assay:}

The antibacterial spectrum of the bacteriocin from Lactobacillus $s p$. was determined using the well diffusion method. (Ogunbanawo et al., 2003)

\section{Statistical Optimization of medium for Production of Bacteriocin:}

The nutrients selection was done according to the flasks which were supporting good growth of the organism. Thus accordingly glucose (A),Fructose (B), lactose(C), sucrose(D), peptone $(\mathrm{E})$, beef extract $(\mathrm{F})$, yeast $\operatorname{extract}(\mathrm{G})$, meat extract(H), $\mathrm{KH}_{2} \mathrm{PO}_{4}(\mathrm{I}), \mathrm{K}_{2} \mathrm{HPO}_{4}(\mathrm{~J}), \mathrm{MgSO}_{4}(\mathrm{~K})$, $\mathrm{MnSO}_{4}(\mathrm{~L})$, Sodium potassium tartrate(M) were selected for statistical optimization process.

\section{2.a Plackett-Burman Design (PBD):}

PBD was used to screen the most important factors influencing bacteriocin production. The fermentation process was carried out in triplicate by using an experimental design with symbol code and level of the variables and the average value was taken as the response. PlackettBurman design had carried by Plackett-Burman, (1946); Djekrif-Dakhmouche et al., (2006). 2.b The Path of the Steepest Ascent Experiment:

To find the neighbourhood of the optimum condition quickly, the method of the steepest ascent was used. The experiments were applied to determine a suitable direction by increasing or decreasing the variables according to the results obtained from the Plackett-Burman design. This experiment was designed by Rodrigues et al., (2006); Han et al., (2011).

\section{2.c Central Composite Design (CCD):}

To describe the nature of the response surface in the optimum region, a central composite design and response surface methodology was performed. This experimental design was carried by Montgomery, (1997); Leaes et al., (2011).

\section{2.d Statistical analyses:}

The PBD, analysis of variance (ANOVA) for the PBD data and the model coefficients were computed with Minitab 14.0 (Minitab Inc., Pennsylvania, USA) software. The Design Expert software (Version 9.0.0, Stat-Ease, Minneapolis, USA) was used for the RSM experimental design and the analysis of variance (ANOVA) for the data. The quality of the polynomial model equation was judged statistically by the coefficient of determination $\mathrm{R}^{2}$, and its statistical significance was tested by an F-test. The 
significance of the regression coefficients was determined by a t-test.

\section{RESULT \& DISCUSSION:}

\section{Statistical Optimization of medium for Production of Bacteriocin 1.a PBD for optimization of medium:}

Plackett-Burman statistical design offers an effective screening procedure and computes the significance of a large number of factors in a few experiments; based on the variables, a PlackettBurman design of the 16 experimental trials with their outcomes is given in Table 1 . The significant levels of each variables were determined by using $t$ test and regression analysis.

The experimental yields of bacteriocin at varied levels of different variables as per PlackettBurman design are given in Table 2. The analysis showed that lactose, peptone, yeast extract, $\mathrm{MgSO}_{4}, \quad \mathrm{KH}_{2} \mathrm{PO}_{4}, \mathrm{~K}_{2} \mathrm{HPO}_{4}$ had a significant influence (at 95\% significant level) on bacteriocin production, while other factors had insignificant influence (below 95\% significant level) on antibacterial activity by Lacobacillus rhamnosus L43. On the basis of statistical testing and the $F$ test applied for the analysis of variance (ANOVA), the F-value was 24.14. The $F$-test with a very low probability value $(0.040)$ shows the high statistical significance of the regression model. The Pareto plot best demonstrates results of Plackett-Burman design that illustrate the absolute relative significance of variables independent of their nature (Figure 1). The ranking of factor estimates in a Pareto chart which displays the magnitude of each factor estimate, it directly shows that the most important factors determining Bacteriocin production from Lactobacillus rhamnosus L43 were Lactose, Peptone, Yeast extract, $\mathrm{MgSO}_{4}$, $\mathrm{KH}_{2} \mathrm{PO}_{4}, \mathrm{~K}_{2} \mathrm{HPO}_{4}$ concentrations while the other factors have insignificant influence.

\section{1.b Optimization of medium by the path of the} steepest ascent experiment:
A steepest ascent experiment was performed before the second-order polynomial model. The design and the steepest ascent experiment are shown in Table 3. The centre point of PBD has been considered as the origin of the path and the path was moved along in which the concentration of peptone and $\mathrm{MgSO}_{4}$ were increasing. Steepest ascent path design was prepared by using regression equation which was obtained by PBD. The regression equation is $\mathrm{mm}=7.39+0.0812$ Glucose +0.0562 Sucrose 0.0187 Lactose - 0.219 Fructose

+0.244 Peptone - 0.0563 Beef extract + 0.160 Malt extract

$+0.906 \mathrm{KH} 2 \mathrm{PO} 4+0.719 \mathrm{~K} 2 \mathrm{HPO} 4+24.4$

$\mathrm{MgSO} 4+9.03 \mathrm{MnSO} 4$

+14.6 Pot.Sod.tartarate +0.187 yeast extract

The response for this point was determined as the average of responses for all the runs. From the results of the path of the steepest ascent, it is clearly seen that the yield profile shows a maximum diameter of zone of inhibition $(20.5 \mathrm{~mm})$ at run 15 i.e. at $7.5 \mathrm{gm} / \mathrm{L}$ of Lactose, $7.5 \mathrm{gm} / \mathrm{L}$ of peptone, $0.5 \mathrm{gm} / \mathrm{L}$ of yeast extract, $0.5 \mathrm{gm} / \mathrm{L}$ of $\mathrm{KH}_{2} \mathrm{PO}_{4}, 1.5 \mathrm{gm} / \mathrm{L}$ of $\mathrm{K}_{2} \mathrm{HPO}_{4}$ and $0.075 \mathrm{gm} / \mathrm{L}$ of $\mathrm{MgSO}_{4}$. It is suggested that this point might be near the region of the maximum antibiotic yield response. Consequently, this point was chosen as the central point of CCD.

\section{1.c Optimization of Medium by Response Surface Methodology:}

Based on the identification of variables by the PBD and the steepest ascent method, the experiments were performed according to a CCD experimental plan. The CCD experimental plan together with results is given in Table 4.

Table 4 shows the observed values of the bacteriocin yield obtained using CCD equation as follows:

$\hat{Y}=\beta_{0}+\beta_{1} X_{1}+\beta_{2} X_{2}+\beta_{11} X_{1}^{2}+\beta_{12} X_{1} X_{2}+\beta_{22} X_{2}^{2}$ 
Where, $\hat{Y}$ was the predicted response (antibiotic yield), $\beta 0, \beta 1, \beta 2, \beta 11, \beta 12$ and $\beta 22$ were the regression coefficients, and $X 1$ and $X 2$ were the coded levels of the independent variables.

In order to predict the maximum production corresponding to the optimum levels of the two variables, a second-order polynomial model was proposed to calculate the optimum levels of these variables. By applying the multiple regression analysis on experimental data, a second order polynomial model in coded unit explains the role of each variable and their second-order interactions in producing Bacteriocin.

\section{Equation:}

$\mathrm{R} 1=+19.49-0.17$ * $\mathrm{A}-0.59$ * $\mathrm{B}-0.53$ * $\mathrm{C}+1.38$ * $\mathrm{AB}+0.88$ * $\mathrm{AC}-1.37$ * $\mathrm{BC}+0.25$ * $\mathrm{A} 2-1.87$ * $\mathrm{B} 2-$ $2.14 * \mathrm{C} 2$

Furthermore, the results of the secondorder response surface model in the form of analysis of variance (ANOVA) were shown in Table 5. The smaller the $P$-value, the more significant is the corresponding coefficient. The Fisher's $\mathrm{F}$ test with a very low probability value demonstrated that the model was highly significant (Myers and Montgomery 2002). Among the model terms, $\mathrm{A}, \mathrm{B}, \mathrm{AB}, \mathrm{A}^{2}$ and $\mathrm{B}^{2}$ had significant effects on production with a probability of not less than $95 \%$.

The fitness of the model can be checked by the determination coefficient $\left(\mathrm{R}^{2}\right)$ and the adjusted determination coefficient (Adj $R^{2}$ ). Here, the value of the $\mathrm{R}^{2}$ was 0.9777 , implying that $97.77 \%$ of the variability in the response could be explained by the model. The value of the Adj $R^{2}$ was 0.950 and it was also high enough to advocate for the significance of the model. In the present experiment, the lower value of CV (3.53\%) indicates a better precision and reliability of the experiments performed. The 3D response surface curve and 2D contour plot (figure 2 and 3 ) are generally the graphical representation of the regression equation. Analysis of response surface plot indicated that lactose and peptone have slight variation in concentrations from zero code value led to an increase in bacteriocin production.

\section{1.d Validation of the optimized condition:}

. The optimized medium included Lactose 20 $\mathrm{gm} / \mathrm{L}$, Peptone $10 \mathrm{gm} / \mathrm{L}$ and $\mathrm{MgSO}_{4}$ 0.10gm/L . Predicted value of the diameter of zone of inhibition against Escherichia coli was $19.48 \mathrm{~mm}$ (maximum response) (Table 6).

Under the optimized conditions, average diameter of zone of inhibition against Escherichia coli was $19.66 \mathrm{~mm}$ which was very closer to the predicted response, in fact, higher than the predicted response. It confirms the authenticity of the model. These results indicate that the optimization of medium through RSM favoured enhanced Bacteriocin production.

The composition of the medium was also shown to have an important role in bacteriocin production (Li et al., 2002). RSM has been successfully used in many studies for optimization of bacteriocin production. However, since factors varied among different strains, this work differs from previous studies (Claderaoliveria et al., 2004) in choosing factors before RSM. However, studies to reduce the cost of the medium have only been recently conducted (Dominguez et al., 2007). In the present study, some nitrogen sources in MRS were used to reduce costs viz., peptone and yeast extract. Earlier, $\mathrm{Li}$ and co-workers 2002 showed that peptone and $\mathrm{KH}_{2} \mathrm{PO}_{4}$ are the two significant factors for bacteriocin production and have the positive effect.

\section{CONCLUSION:}

The bacterial suspension of Lactobacillus rhamnosus L43 has grown in MRS and mMRS Broth had the best inhibitory activity against wide spectrum of bacteria. The present study demonstrated the production of bacteriocin by 
Lactobacillus rhamnosus $L 43$ which has grown at nutrient medium. RSM was used to determine the effects of three important factors of peptone, lactose, $\mathrm{MgSO}_{4}$ on bacteriocin production from broth. Linear, quadratic and interaction effects of these variables on bacteriocin production were determined. The statistical approach proved to be beneficial in optimizing a medium for bacteriocin production by Lactobacillus rhamnosus L43.. The model generated in this study satisfied all the necessary arguments for its use in optimization. By fitting the experimental data to a second-order polynomial equation, the optimum levels of important response variables were determined. Using the optimum levels of fermentation parameters, a maximum bacteriocin production of $19.66 \mathrm{~mm}$ was obtained. This study indicates that the medium design using statistical technique such as Plackett-Burman Design, RSM can be very useful in improving the production of bacteriocin production by Lactobacillus rhamnosus L43. and in similar bioprocesses. The optimized medium not only allowed the increase in bacteriocin activity, but also reduced the cost of the medium.

\section{ACKNOWLEDGEMENT:}

The authors are extending their thanks to Director, Government Institute of Science, Aurangabad, Maharashtra. We express our gratitude to WOS-A, DST, Delhi for accepting project (Ref No: SR/WOS-A/LS-210/2013).

\section{REFERENCES:}

Abo-Amer, A.E. (2011). Optimization of the bacteriocin production by L. acidophilus AA11, a strain isolated from Egyptian cheese. Ann Microbiology. 61, 445-452.

Chen H and D.G. Hoover (2003). Bacteriocins and their Food Applications. Comprehensive Reviews in Food Science and Food Safety. 2, 83-97
Cladera-Olivera, F., Caron, G. R. and Brandelli, A. (2004). Bacteriocin production by Bacillus lechiniformis P40 in cheese whey using response surface methodology. Biochem. Eng. J. 21, 53-58.

Djekrif-Dakhmouche, S., Gheribi-Aoulmi, Z., Meraihi, Z., Bennamoun, L. (2006). Application of a statistical design to the optimization of culture medium for aamylase production by Aspergillus niger ATCC 16404 grown on orange waste powder. J Food Eng. 73(2), 190-197.

Dominguez APM, Bizani D, Cladera-Olivera F, Brandelli A (2007).Cerein 8A production in soybean protein using response surface methodology. Biochem. Eng. J., 35: 238243.

Han, B., Yu, Z., Liu, L., Ma, Q., and Zhang, R. (2011). Optimization of bacteriocin production by Lactobacillus plantarum YJG, isolated from the mucosa of the gut of healthy chickens. African Journal of Microbio. Research. 5(10), 1147-1155. DOI: 10.5897/AJMR10.643

Keren, T., Yarmus, M., Halevy, G., Shapira, R. (2004). Immuno detection of the bacteriocin lacticin RM: Analysis of the influence of temperature and Tween 80 on its expression and activity. Appl. Environ. Microbiol. 70, 2098-2104.

Kumar, M., Jain, A.K., Ghosh, M., Ganguli, A. (2012). Statistical optimization of physical parameters for enhanced bacteriocin production by L. casei. Biotechnol Bioprocess Eng. 17(3), 606-616.

Leal-Sanchez, M.V., Jimenez-Diaz, R., Maldonado-Barragan, A., GarridoFernandez, A., and Ruiz-Barba, J.L. (2002). Optimization of bacteriocin production by batch fermentation of Lactobacillus plantarum LPCO10. Appl. Environ. Microbiol. 68, 4465-4471. 
Li C, BaI JH, Cai ZL, Ouyang F (2002). Optimization of a cultural medium for bacteriocin production by Lactococcus lactis using response surface methodology. J. Biotechnol., 93: 27-34.

Magdalena Polak-berecka1 et al. (2010). Optimization of Medium Composition for Enhancing Growthof Lactobacillus rhamnosus PEN Using Response Surface Methodology. Polish Journal of Microbiology 2010, Vol. 59, No2, 113-118.

Mataragas, M., Drosinos, E.H., Tsakalidou, E. and Metaxopoulos, J. (2004). Influence of nutrients on growth and bacteriocin production by Leuconostoc mesenteroides L124 and Lactobacillus curvatus L442. Antonie van Leeuwenhoek. 85, 191-198.

Montgomery, D.C. (1997). Response surface methods and other approaches to process optimization. In: Montg omery DC, editor. Design and analysis of experiments. New York: John Wiley and Sons. 427-510.

Plackett, R.L. and Burman, J.P. (1946). The design of optimum multifactorial experiments. Biometrika. 33(4), 305-325.

Rodriguez, E., Martinez, M.I., Horn, N., Dodd, H.M. (2003). Heterologous production of bacteriocins by Lactic Acid Bacteria. International Journal of Food Microbiology. 80, 101-116.
Suganthi, V., Mohanasrinivasan V. (2015). Optimization studies for enhanced bacteriocin production by Pediococcus pentosaceus KC692718 using response surface methodology. Journal of Food Science Technology. 52(6), 3773-3783. DOI: 10.1007/s 13197-014-1440-5.

Todorov, S.D. (2008). Bacteriocin production by L. plantarum AMA-K isolated from Amasi, a Zimbabwean fermented milk product and study of the adsorption of bacteriocin AMAK to Listeria sp. Braz J Microbiol. 39, 178187.

Todorov, S.D. and Dicks, L.M.T. (2006). Effect of medium components on bacteriocin production by Lactobacillus plantarum strains ST23LD and ST341LD, isolated from spoiled olive brine. Microbiol Res. 161, 102108.

Ogunbanawo, S.T., Sanni, A.I., Onnilude, A.A., (2003). Characterization of bacteriocin produced by Lactobacillus plantarum F1 and Lactobacillus brevis OG1. African Journal of Biotechnoogy. 2(8):219-227.

Trinetta V, Rollini M, Manzoni M (2008). Development of a low cost culture medium for sakacin A production by L. sakei. Process Biochem., 43: 1275-1280. 
Table 1: PBD for evaluating variables influencing Bacteriocin

\begin{tabular}{|c|c|c|c|c|c|c|c|c|c|c|c|c|c|c|c|}
\hline Run & A & B & $\mathrm{C}$ & D & E & F & G & $\mathrm{H}$ & I & $\mathrm{J}$ & $\mathrm{K}$ & L & M & $\begin{array}{c}\text { Zone of } \\
\text { inhibition } \\
(\mathrm{mm})\end{array}$ & $\begin{array}{l}\text { Predicted } \\
\text { values }\end{array}$ \\
\hline 1 & 0.75 & 0.75 & 0.75 & 1.25 & 0.25 & 0.25 & 0.5 & 0.5 & 0.15 & 0.05 & 0.0075 & 0.0005 & 0.005 & 16 & 16.56 \\
\hline 2 & 1.25 & 0.75 & 1.25 & 1.25 & 0.75 & 0.75 & 0.05 & 0.5 & 0.05 & 0.05 & 0.0075 & 0.0005 & 0.0005 & 13 & 13.12 \\
\hline 3 & 0.75 & 0.75 & 0.75 & 0.75 & 0.25 & 0.25 & 0.05 & 0.05 & 0.05 & 0.05 & 0.0025 & 0.0005 & 0.0005 & 17.5 & 17.43 \\
\hline 4 & 1.25 & 0.75 & 1.25 & 0.75 & 0.75 & 0.75 & 0.5 & 0.05 & 0.15 & 0.05 & 0.0025 & 0.0005 & 0.005 & 17 & 17.12 \\
\hline 5 & 0.75 & 0.75 & 1.25 & 0.75 & 0.25 & 0.75 & 0.5 & 0.5 & 0.05 & 0.15 & 0.0025 & 0.005 & 0.005 & 14 & 14.43 \\
\hline 6 & 1.25 & 1.25 & 0.75 & 1.25 & 0.25 & 0.75 & 0.5 & 0.5 & 0.15 & 0.15 & 0.0025 & 0.0005 & 0.0005 & 10 & 9.8 \\
\hline 7 & 0.75 & 1.25 & 1.25 & 0.75 & 0.75 & 0.25 & 0.5 & 0.05 & 0.15 & 0.15 & 0.0075 & 0.0005 & 0.0005 & 20 & 20.56 \\
\hline 8 & 1.25 & 1.25 & 1.25 & 0.75 & 0.25 & 0.25 & 0.5 & 0.5 & 0.05 & 0.05 & 0.0075 & 0.005 & 0.0005 & 15.5 & 15.93 \\
\hline 9 & 1.25 & 1.25 & 1.25 & 1.25 & 0.25 & 0.25 & 0.05 & 0.05 & 0.15 & 0.05 & 0.0025 & 0.005 & 0.005 & 18.5 & 18.8 \\
\hline 10 & 1.25 & 1.25 & 0.75 & 0.75 & 0.25 & 0.75 & 0.05 & 0.05 & 0.05 & 0.15 & 0.0075 & 0.0005 & 0.005 & 16.5 & 16.12 \\
\hline 11 & 0.75 & 0.75 & 1.25 & 1.25 & 0.25 & 0.75 & 0.05 & 0.05 & 0.15 & 0.15 & 0.0075 & 0.005 & 0.0005 & 15.0 & 16.3 \\
\hline 12 & 0.75 & 1.25 & 0.75 & 1.25 & 0.75 & 0.75 & 0.5 & 0.05 & 0.05 & 0.05 & 0.0025 & 0.005 & 0.0005 & 14.5 & 14.06 \\
\hline 13 & 1.25 & 0.75 & 0.75 & 0.75 & 0.75 & 0.25 & 0.05 & 0.5 & 0.15 & 0.15 & 0.0025 & 0.005 & 0.0005 & 13 & 15.06 \\
\hline 14 & 0.75 & 1.25 & 1.25 & 1.25 & 0.75 & 0.25 & 0.05 & 0.5 & 0.05 & 0.15 & 0.0025 & 0.0005 & 0.005 & 18 & 18.43 \\
\hline 15 & 1.25 & 0.75 & 0.75 & 1.25 & 0.75 & 0.25 & 0.5 & 0.05 & 0.05 & 0.15 & 0.0075 & 0.005 & 0.005 & 20.5 & 20.87 \\
\hline 16 & 0.75 & 1.25 & 0.75 & 0.75 & 0.75 & 0.75 & 0.05 & 0.5 & 0.15 & 0.05 & 0.0075 & 0.005 & 0.005 & 19.5 & 19.6 \\
\hline
\end{tabular}


Table 2: Estimated effect from the results of PBD

\begin{tabular}{|c|c|c|c|c|c|}
\hline \multicolumn{6}{|c|}{ Estimated Effects and Coefficients For Mm (Coded Units) } \\
\hline Term & Effec & t Coef & SE Co & $\mathbf{T}$ & $\mathbf{P}$ \\
\hline \multicolumn{2}{|c|}{ Constant } & 5.844 & 63 & \multicolumn{2}{|c|}{0.000} \\
\hline Glucose & 1.188 & 0.594 & 0.1563 & 3.80 & 0.063 \\
\hline Sucrose & 0.812 & 0.406 & 0.1563 & 2.60 & 0.122 \\
\hline Fructose & 0.062 & 0.031 & 0.1563 & 0.20 & 0.860 \\
\hline Lactose & -2.187 & -1.094 & 0.1563 & -7.00 & 0.020 \\
\hline Peptone & 2.687 & 1.344 & 0.1563 & 8.60 & 0.013 \\
\hline Beef Ext & -0.438 & -0.219 & 0.1563 & -1.40 & 0.296 \\
\hline Malt Ext & 1.062 & 0.531 & 0.1563 & 3.40 & 0.077 \\
\hline $\mathrm{KH}_{2} \mathrm{PO}_{4}$ & 2.187 & 1.094 & 0.1563 & 7.00 & 0.020 \\
\hline $\mathrm{K}_{2} \mathrm{HPO}_{4}$ & 1.688 & 0.844 & 0.1563 & 5.40 & 0.033 \\
\hline $\mathrm{MgSO}_{4}$ & 2.562 & 1.281 & 0.1563 & 8.20 & 0.015 \\
\hline $\mathrm{MnSO}_{4}$ & 0.687 & 0.344 & 0.1563 & 2.20 & 0.159 \\
\hline Pot.Sod. & 1.313 & 0.656 & 0.1563 & 4.20 & 0.052 \\
\hline Yeast Ex & 1.687 & 0.844 & 0.1563 & 5.40 & 0.033 \\
\hline
\end{tabular}


Pareto Chart of the Standardized Effects (response is $\mathrm{mm}$, Alpha $=.05$ )

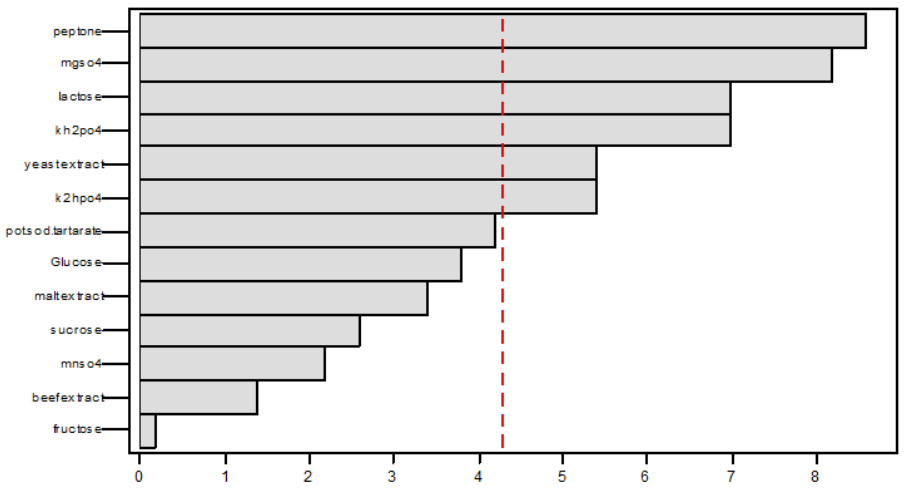

Fig 1 : Pareto chart

Table 3: The path of steepest ascent experiment for optimization of efficient variables

\begin{tabular}{|c|c|c|c|c|c|c|c|}
\hline $\begin{array}{c}\text { Run } \\
\mathrm{Gm} / 100 \mathrm{ml}\end{array}$ & Lactose & Peptone & $\mathrm{KH}_{2} \mathrm{PO}_{4}$ & $\mathrm{~K}_{2} \mathrm{HPO}_{4}$ & $\mathrm{MgSO}_{4}$ & $\begin{array}{c}\text { Yeast } \\
\text { extract }\end{array}$ & $\begin{array}{c}\text { Zone of } \\
\text { inhibition } \\
(\mathrm{mm})\end{array}$ \\
\hline 1 & 1 & 0.5 & 0.1 & 0.1 & 0.05 & 0.25 & 18.5 \\
\hline 2 & 1.025 & 0.554 & 0.1485 & 0.1105 & 0.015 & 0.2504 & 16 \\
\hline 3 & 1.05 & 0.6085 & 0.1975 & 0.1215 & 0.020 & 0.2508 & 13 \\
\hline 4 & 1.075 & 0.6625 & 0.246 & 0.1325 & 0.0317 & 0.2512 & 10.5 \\
\hline 5 & 1.1 & 0.7165 & 0.295 & 0.143 & 0.042 & 0.2516 & 12 \\
\hline 6 & 1.125 & 0.771 & .0 .34 & 0.1515 & 0.053 & 0.252 & 13 \\
\hline 7 & 1.15 & 0.825 & 0.3925 & 0.165 & 0.064 & 0.2524 & 9 \\
\hline
\end{tabular}

Table 4: CCD for optimization of medium and the corresponding responses

\begin{tabular}{|c|c|c|c|c|}
\hline Run & $\begin{array}{c}\text { Factor 1 } \\
\text { A: Lactose gm/L }\end{array}$ & $\begin{array}{c}\text { Factor } 2 \\
\text { B: Peptone gm/L }\end{array}$ & $\begin{array}{c}\text { Factor 3 } \\
\text { C: MgSO4 gm/L }\end{array}$ & $\begin{array}{c}\text { Response 1 } \\
\text { R1 MM }\end{array}$ \\
\hline 1 & 22 & 12 & 0.12 & 16 \\
\hline 2 & 20 & 10 & 0.1 & 19.5 \\
\hline 3 & 20 & 10 & 0.1 & 19.5 \\
\hline 4 & 20 & 10 & 0.1 & 19.5 \\
\hline 5 & 22 & 8 & 0.12 & 19.5 \\
\hline 6 & 20 & 10 & 0.1 & 15.5 \\
\hline 7 & 20 & 6.63641 & 0.1 & 12 \\
\hline 8 & 20 & 10 & 0.133636 & 13 \\
\hline 9 & 22 & 8 & 0.08 & 17.5 \\
\hline 10 & 18 & 12 & 0.08 & 19.5 \\
\hline 11 & 18 & 8 & 0.08 & 11.5 \\
\hline 12 & 20 & 10 & 0.1 & 18 \\
\hline 13 & 18 & 12 & 0.12 & 19.5 \\
\hline 14 & 22 & 12 & 0.08 & 12.5 \\
\hline 15 & 18 & 8 & 0.12 & 19.5 \\
\hline 16 & 23.3636 & 10 & 0.1 & 2.5 \\
\hline 17 & 20 & 13.3636 & 0.1 & \\
\hline 18 & 20 & 10 & 0.1 & 0.1 \\
\hline 19 & 20 & 10 & 0.1 & \\
\hline 20 & 16.6364 & 10 & & \\
\hline
\end{tabular}


Table 5: ANOVA for response surface quadratic model for optimization of medium

\begin{tabular}{|c|c|c|c|c|c|}
\hline Sources & $\begin{array}{c}\text { Sum of } \\
\text { squares }\end{array}$ & $\mathrm{df}$ & $\begin{array}{c}\text { Mean } \\
\text { Square }\end{array}$ & F value & $\begin{array}{c}\text { p-Value } \\
\text { probe }>\mathrm{F}\end{array}$ \\
\hline Model & 156.57 & 9 & 17.40 & 48.69 & $<0.0001$ \\
\hline A-Lactose & 0.41 & 1 & 0.41 & 1.15 & 0.3097 \\
\hline B-Peptone & 4.74 & 1 & 4.74 & 13.27 & 0.0049 \\
\hline C-MgSO4 & 3.80 & 1 & 3.80 & 10.64 & 0.0085 \\
\hline $\mathrm{AB}$ & 15.13 & 1 & 15.13 & 42.34 & $<0.0001$ \\
\hline $\mathrm{AC}$ & 6.13 & 1 & 6.13 & 17.14 & 0.0020 \\
\hline $\mathrm{BC}$ & 15.12 & 1 & 15.12 & 42.34 & $<0.0001$ \\
\hline $\mathrm{A}^{2}$ & 0.91 & 1 & 0.91 & 2.54 & 0.1418 \\
\hline $\mathrm{B}^{2}$ & 50.40 & 1 & 50.40 & 141.09 & $<0.0001$ \\
\hline $\mathrm{C}^{2}$ & 65.71 & 1 & 65.71 & 183.93 & $<0.0001$ \\
\hline Residual & 3.57 & 10 & 0.36 & & \\
\hline Lack of Fit & 3.57 & 5 & 0.71 & & \\
\hline Pure error & 0.000 & 5 & 0.000 & & \\
\hline Cor Total & 160.14 & 19 & & & \\
\hline
\end{tabular}

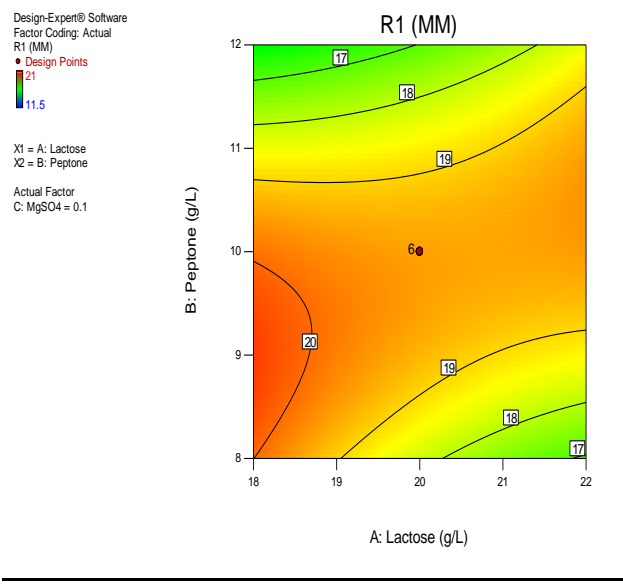

Fig.2 : 2D Contour Plot

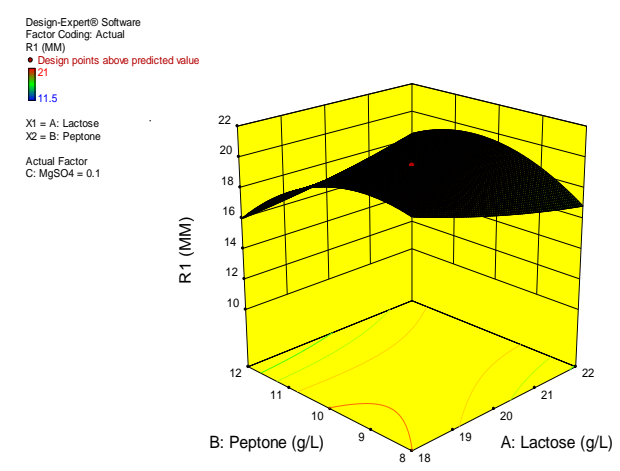

Fig.3: 3D Response Surface Curve

\section{1.d Validation of the optimized condition:}

Table 6: Confirmation report for optimization for medium by RSM

\begin{tabular}{|c|c|c|c|c|c|c|c|c|}
\hline Factor & Name & Level & $\begin{array}{c}\text { Low } \\
\text { Level }\end{array}$ & $\begin{array}{c}\text { High } \\
\text { Level }\end{array}$ & $\begin{array}{c}\text { Std. } \\
\text { Dev. }\end{array}$ & Coding & & \\
\hline A & Lactose & 20.00 & 18.00 & 22.00 & 0.000 & Actual & & \\
\hline B & Peptone & 10.00 & 8.00 & 12.00 & 0.000 & Actual & & \\
\hline C & MgSO $_{4}$ & 0.100 & 0.080 & 0.12 & 0.000 & actual & & \\
\hline Response & $\begin{array}{c}\text { Predicted } \\
\text { Mean }\end{array}$ & $\begin{array}{c}\text { Predicted } \\
\text { Median } \underline{1}\end{array}$ & Observed & Std. Dev. & N & $\begin{array}{c}\text { SE } \\
\text { Pred }\end{array}$ & $\begin{array}{c}95 \% \\
\text { PI } \\
\text { Low }\end{array}$ & $\begin{array}{c}\text { Data } \\
\text { Mean }\end{array}$ \\
\hline R1 & 19.4886 & 19.4886 & - & 0.597703 & 1 & 0.65 & 18.05 & \\
\hline
\end{tabular}

